\title{
In Silico Analysis of Actin Gene as a Candidate for DNA Non-Halal Detection Base on Real-Time PCR
}

\author{
Seagames Waluyo ${ }^{1 *}$, Jekmal Malau², Muhareva Raekiansyah ${ }^{3}$, Edwin Yulian $^{4}$, Imam Hardiman $^{5}$ \\ 1,2,3,4,5PT. Sciencewerke Indonesia, Jl. Palmerah Barat No.25, RT.1/RW.15, Palmerah, Kec. Palmerah, Kota \\ Jakarta Barat, Daerah Khusus Ibukota Jakarta 11480, Indonesia \\ ${ }^{5}$ Department of Pharmacy, Faculty of Pharmacy and Science, Universitas Prof. Dr. HAMKA, Jl. Delima II Gg. \\ 4, RT.9/RW.3, Malaka Sari, Kec. Duren Sawit, Kota Jakarta Timur, Daerah Khusus Ibukota Jakarta 13460, \\ Indonesia \\ e-mail:games.agro@gmail.com*1,jekmal@sciencewerke.com², m.raekiansyah@gmail.com², \\ edwin.yulian@yahoo.com
}

*Corresponding Author

Received: June 02, 2021; Accepted: August 29, 2021

\begin{abstract}
Actin genes are genes that are common in organisms, and their expression is constitutive. These genes are used for gene normalization and internal control of DNA extraction, but the actin gene is not widely used for halal certification tests. Bioinformatic studies help to analyze the experiment through in silico more deeply before the experiment is carried out in laboratory, making it more efficient and time effective. uMelt is an analysis to predict the melting curve of target amplification in real-time PCR. Real-time PCR has been widely used for screening and detection of pork content in a product. This research aimed to explore actin gene as a candidate for testing pork using qPCR. The study was carried out in two main stages, namely alignment of the DNA sequence and analysis of the melting curve using the uMelt approach. The results showed a set of actin genes containing conserved regions that can be used as degenerate primers with different family-type coverages. Melting curve prediction with uMelt shows differences in tm peaks so as the types of samples can be easily identified. The use of bioinformatic applications such as uMelt helps in the simulation of predicting the melting curve to increase the precision of the analysis.
\end{abstract}

Keywords: Actin gene, halal product, real-time PCR, uMelt

\section{Introduction}

Indonesia is the largest Muslim country with $87.18 \%$ of its citizens is Muslims. Therefore, the potential of halal market is promising. To protect Muslim citizens, the Indonesian government has an agency to regulate halal-guaranteed products, namely BPJPH (Halal Product Security Agency) (Aminuddin, 2016). Halal-guaranteed products include raw materials, production processes to the final product (Faridah, 2019). One of the concerns is the use of pork and its derivatives. Pork is widely used for meatball mixtures, emulsions, and trypsinization in cell culture, vaccines, candies, and medicine. It gives a challenge to develop a robust, accurate, and sensitive method for pork detection.

Real-time PCR (qPCR) as a DNA-based detection has been widely used to detect porcine. This method is able to detect at the level of the raw material to the end product (Rachmawati et al., 2018; Raharjo et al., 2019; Widayat et al., 2019). The advantage of this method is high level of accuracy and sensitivity to detect and quantify target in samples. The advantages of this method are high sensitivity, high specificity, and no post-analysis after the PCR process is complete. The amplification process runs in a live stream (real-time) on the monitor screen. Intercalating dye and probe are types of fluorescent dye in use because the accumulated fluorescence of this chemical is equal to the number of amplicons produced. In addition, the PCR composition consists of DNA template, primer and master mix containing real-time PCR buffer, Taq polymerase, nucleotides, fluorescence dye (S. A. Bustin, 2004).

Primer is a key component in determining the success of porcine detection with qPCR. Primers work by starting the amplification of genetic material by annealing at very specific sites on DNA. qPCR has been successfully used to detect porcine DNA contamination in food products such as bread, meatballs and candies, and non-food products, such as bread brushes, moisturizers, soaps, cosmetics, and capsules (M. J. Kim \& Kim, 2019; Y. S. Kim et al., 2018; Mohamad et al., 2018; Mustaqimah et al., 2021; Septiani, 2021; Sudjadi et al., 2016; Tan et al., 2020; Tanabe et al., 2007; Widayat et al., 2019). Currently, primer Cytochrome oxidase I (col) and Cytochrome B $(c y b)$ gene located in mtDNA region is popular for porcine-specific detection. The problem with this target is that it is very specific to the pig 
species but cannot detect the presence of other sources outside of its species. Therefore, other alternative targets are needed to be able to screen for the presence of other sources.

The $\beta$-actin (act) gene has a high conserved region, ability in eukaryotic cells, and stable expression in cell (Zhu et al., 2013). This gene serves as endogenous gene in PCR such as normalization expression gene, quality control DNA extraction, and amplification PCR (Rebouças et al., 2013; Waluyo et al., 2016; Panina et al., 2018). Presently, this gene has also been successfully used in digital PCR (dPCR) for the quantification of porcine contamination (Cai et al., 2014; Tan et al., 2020). The act gene is present in all eukaryotic cells, so that this gene has the potential to be used for non-halal contamination screening in products. The in-silico approach can be used for identification of candidate primers, PCR amplicon, and melting curve prediction. This study aims to explore the actin gene through in silico for the detection of the presence of porcine and its accompaniment for the detection of non-halal contaminants.

\section{Materials and Methods}

\subsection{Sample Preparation}

Sample Act (actin) gene sequences were taken from NCBI (National Center for Biotechnology Information) (https://www.ncbi.nlm.nih.gov/nucleotide) in FASTA format. The sequences analyzed were obtained from cattle (Bos taurus); horse (Equus caballus); dog (Canis lupus familiaris); orangutans (Pongo abelii); chicken (Gallus gallus); porcine (Sus sucrofa), and rat (Rattus novergius) with accession number NCBI is NM_173979.3; NM_001081838.1; NM_205518.1; NM_001195845.2; NM_001133354.1; XM_003124280.5 and NM_031144.3.

\subsection{In-silico Analysis}

The experiment used 2 steps; the first was the sequence alignment using BioEdit software (Hall, 2007), and the second is predicting the melting curve using uMelt (Dwight et al., 2014). Each sequence was downloaded and joined together in a FASTA format file. The ClustalW protocol was used in BioEdit software to align from multiple sequences. Furthermore, the preserved region was selected as the amplification of target region and used as the forward and reverse primary sets with a size of $<200$ bp. The amplification region contained a specific region of each sample sequence. Next, the amplification regions were analyzed using uMelt (https://www.dna-utah.org/umelt/quartz/um.php). The amplification region sequence was entered into the sequence box. The prediction curves used conditions of Mono $+20 \mathrm{mM}$ and free $\mathrm{Mg}++3 \mathrm{mM}$ and readings every $0.1^{\circ} \mathrm{C}$. Each curve produced a $\mathrm{Tm}$ (temperature melting) value, and the next image was carried out, all the melting curve images were overlaid.

\section{Results and Discussion}

Sequence analysis used BioEdit software to generate PCR primer and amplicon candidates by aligning the sequences. The size amplicon candidates are $131 \mathrm{bp}$ containing conserved sequences as PCR primers and species-specific regions. The conserve sequence as generated primer with sequence is forward 5'-GCTACAGCTTCACCACCAC-3' and reverse 5'-TAGCTCTTCTCCAGGGA-3'. Primer was the main component in qPCR to start amplification and will be hybridized to the target region. Good characteristic primers selected have GC content percentage of 55\% in forward and 52\% in reverses at annealing temperatures of $56.46^{\circ} \mathrm{C}$ and $52.42^{\circ} \mathrm{C}$. Harpin analysis showed that each primer has 4 structures of Self complementarity and Self $3^{\prime}$ complementarity forward is 0 and reverse is 4 . This analysis is in accordance with the description of the mFold analysis which shows the presence of a harpin structure at 4 amplicon points (Figure 2). Good qPCR primer design was amplicon <150 bp, GC content between $40-60 \%$ with melting temperature of $55-65^{\circ} \mathrm{C}$ (S. Bustin \& Huggett, 2017; Taylor et al., 2010). 

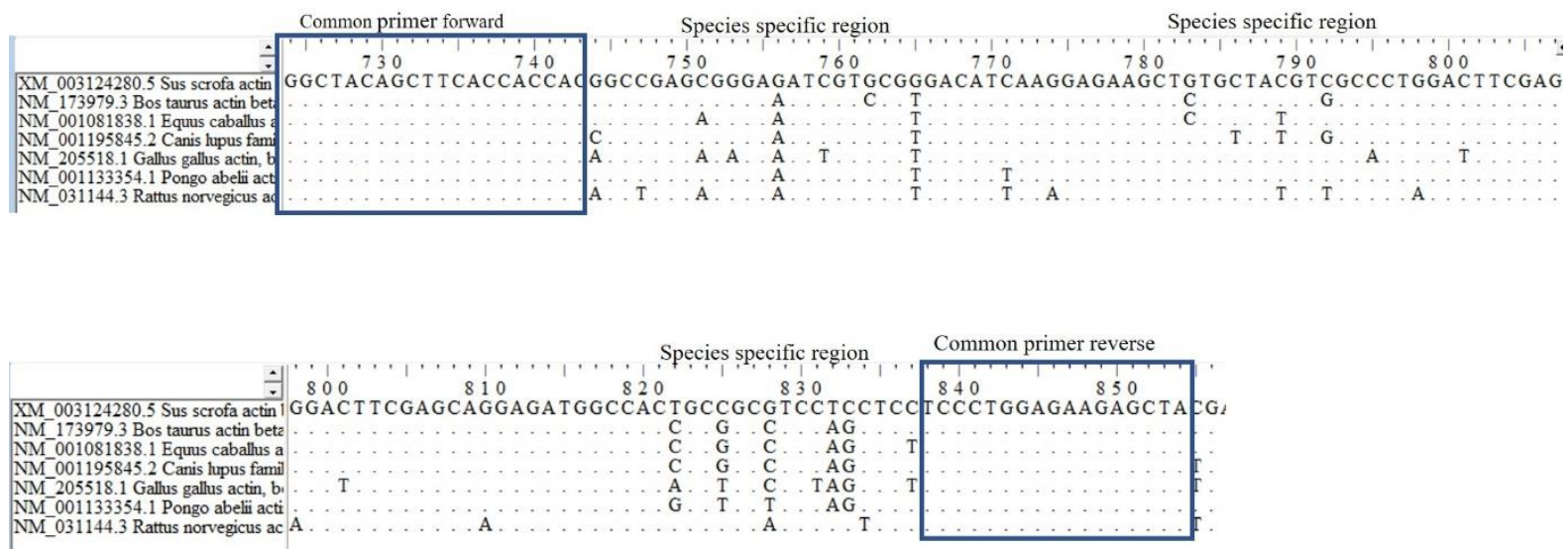

Figure 1. Alignment analysis using BioEdit to identify candidate generate primer in actin gene

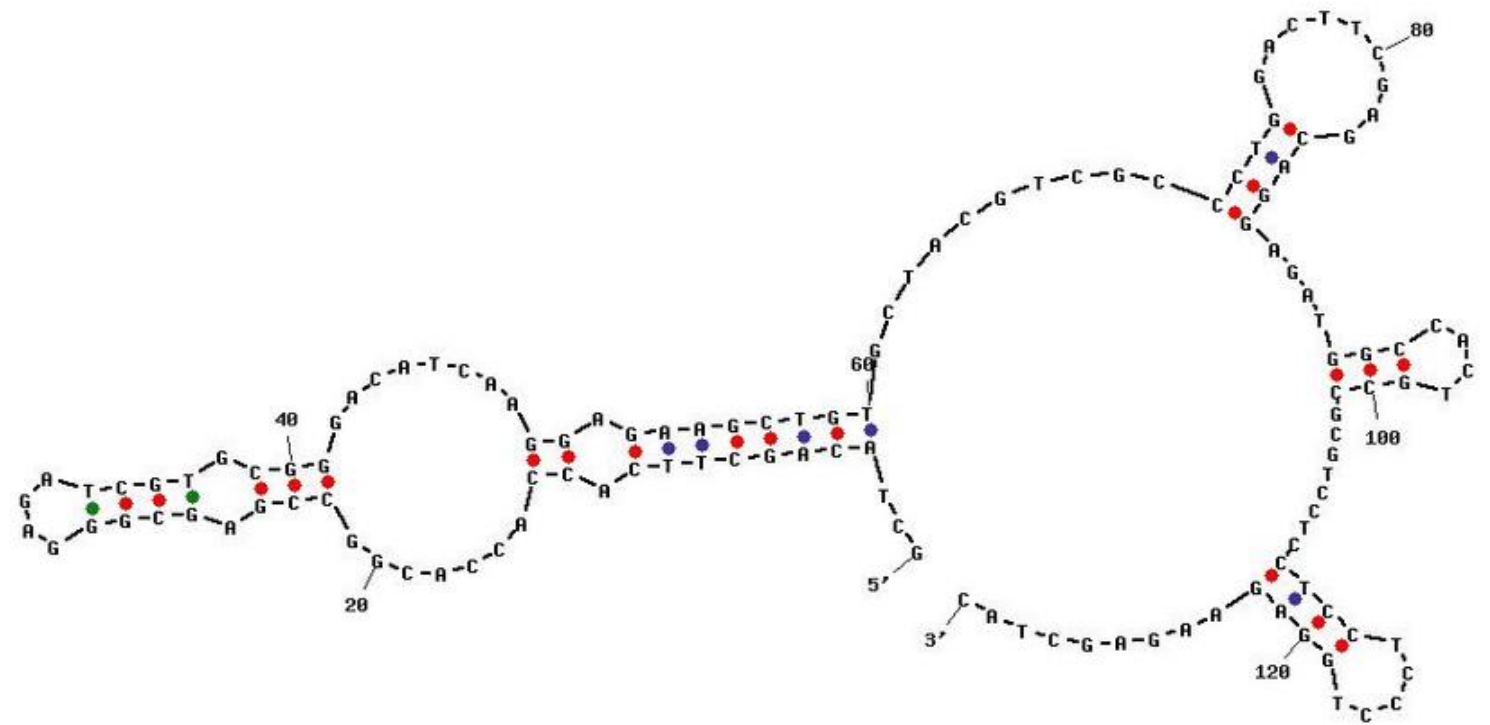

Figure 2. Mfold analysis amplicon target from generates primer actin (https://www.idtdna.com/calc/analyzer).

The uMelt program is aimed to predict the melting temperature $(\mathrm{Tm})$ to differentiate each sample. Between general primers, there is a specific region which is able to distinguish specific regions from each species. The variant nucleotide will produce different melting temperatures. The results showed that the $\mathrm{Tm}$ amplicon candidate value of the selected area has a high range between $85-89^{\circ} \mathrm{C}$, and each curve could differentiate one from the other (Table 1). Dogs and rat have Tm samples which are not significant, so it will be difficult to distinguish them, both are non-halal types. Interestingly, the curve of porcine is significantly separated from the others due to the lower Tm temperature $\left(84.9^{\circ} \mathrm{C}\right)$, so it makes a quick indicator of its presence (Figure 3).

Table 1. Specific Temperature Tm from candidate amplicon for Each Target

\begin{tabular}{cccccccc}
\hline Species & B. taurus & E. caballus & C. lupus familiaris & P. abeli & G. gallus & S. sucrofa & R. novergius \\
\hline $\operatorname{Tm}\left({ }^{\circ} \mathrm{C}\right)$ & 88.9 & 87.8 & 88.2 & 85.7 & 89.2 & 84.9 & 88.1 \\
\hline
\end{tabular}




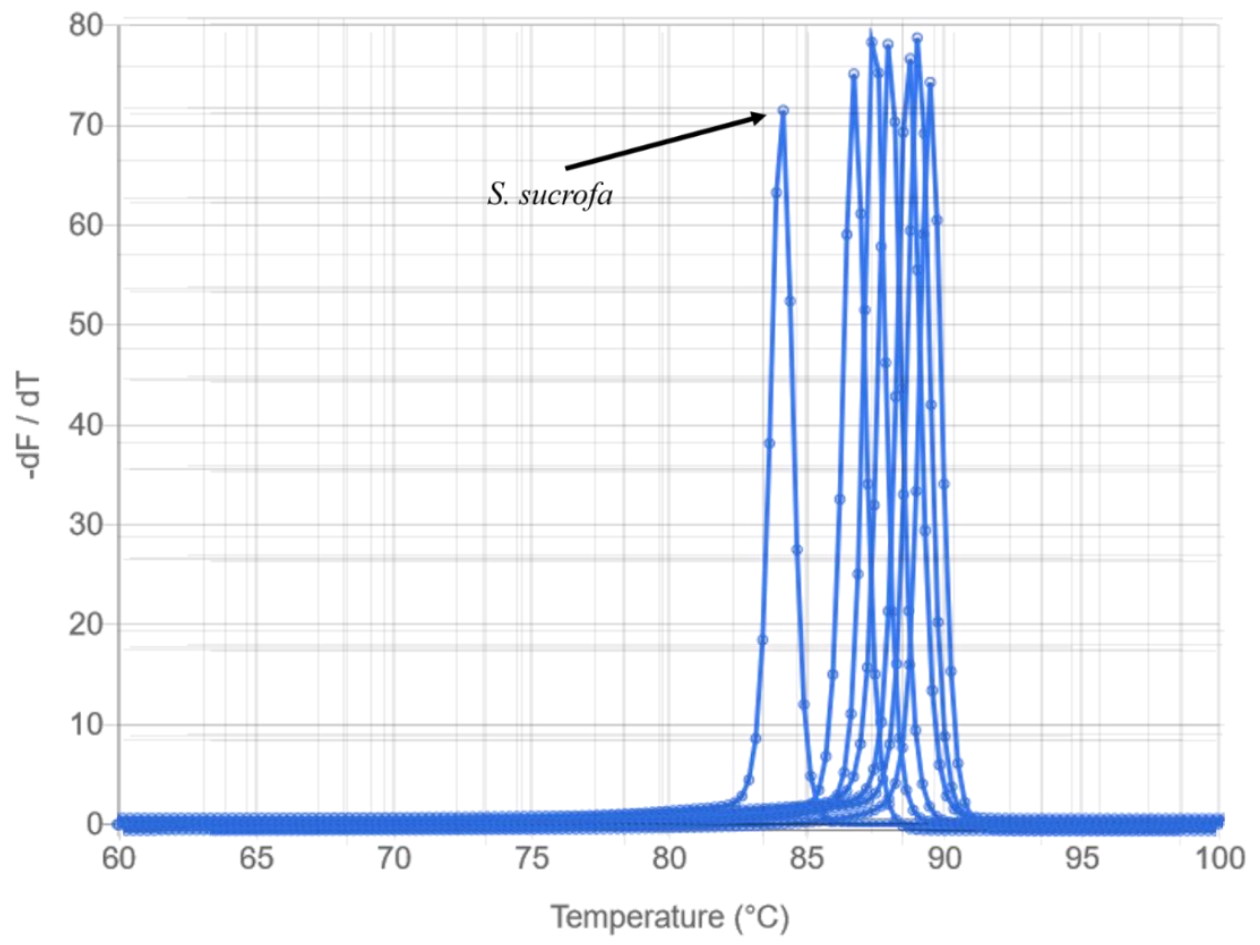

Figure 3. The Curve of Tm Values Analyzed by uMelt in Each Target

The uMelt had successfully predicted the Tm value of each sample as shown in the form of a melting curve. Differences in Tm values varied greatly between 0.1 to $4.3^{\circ} \mathrm{C}$, so that there was no overlap between targets. It was interesting that the peak of porcine had a considerable distance compared to the others. The lowest $\mathrm{Tm}$ value was $84.9^{\circ} \mathrm{C}$ and had a difference of $2.5^{\circ} \mathrm{C}$ when compared to the others (Figure 3). The advantage of this software was that $\mathrm{Tm}$ simulation paid attention to the reagent composition such as the $\mathrm{MgCl}^{+}$content, salt, and the reading resolution, so that it was closer to actual conditions. In addition, this analysis was useful for predicting the profile of the post-PCR curve, so that it could reduce the experiment time.

The melting curve was matched between uMelt and the qPCR machine. Melt peak parameter ($\mathrm{df} / \mathrm{dr}$ compared to temperature) resulted from the conversion of post qPCR. The data generated is the TM value calculated from the \%GC percent and the size of the amplicon. Processed by the qPCR machine, the amplicons produced from the amplification step were denatured from the annealing temperature to $95^{\circ} \mathrm{C}$ with a reading of each increase of $0.5-0.01^{\circ} \mathrm{C}$. SYBR and Evagreen are types of intercalating dye to produce a melting curve. This reagent is compatible with all types of qPCR machines. Thus, the development of detection using intercalating dye using a melting curve has the potential to be widely used in qPCR machines.

\section{Conclusion}

The results of the in-silico analysis of actin gene show the melting curve can easily distinguish of porcine and other species to determine halal products. The success of differentiating the source is due variation sequence in specific region that produces a specific $\mathrm{Tm}$. Further research, laboratory testing of candidate primers using PCR on various sample sources is needed to prove the accuracy of Tm predictions.

\section{References}

Aminuddin, M. Z. (2016). Sertifikasi Produk Halal: Studi Perbandingan Indonesia dan Thailand. SHAHIH : Journal of Islamicate Multidisciplinary, 1(1), 2527-8126.

Ballin, N. Z., Vogensen, F. K., \& Karlsson, A. H. (2009). Species determination - Can We Detect and Quantify Meat Adulteration?. Meat Science 83(2), 165-174.

Bustin, S. A. (2004). A-Z of quantitative PCR. La Jolla, CA: International University Line.

Bustin, S., \& Huggett, J. (2017). qPCR Primer Design Revisited. In Biomolecular Detection and Quantification 14, 19-28.

Cai, Y., Li, X., Lv, R., Yang, J., Li, J., He, Y., \& Pan, L. (2014). Quantitative Analysis of Pork and Chicken Products by Droplet Digital PCR. BioMed Research International, 14, 1-6. 
Dwight, Z. L., Palais, R., Kent, J., \& Wittwer, C. T. (2014). Heterozygote PCR Product Melting Curve Prediction. Human Mutation, 35(3), 278-282.

Faridah, H. D. (2019). Sertifikasi Halal Di Indonesia: Sejarah, Perkembangan dan Implementasi. Journal of Halal Product and Research, 2(2), 68-78.

Hall, T. A. (2007). BioEdit: a User-Friendly Biological Sequence Alignment Editor and Analysis Program for Windows 95/98/NT. Nucl Acids Symp Ser 41: 95-98 (1999). Nucleic Acids Symposium Series, 41(41), 95-98.

Kim, M. J., \& Kim, H. Y. (2019). A fast multiplex real-time PCR assay for simultaneous detection of pork, chicken, and beef in commercial processed meat products. $L W T, 114,1-6$.

Kim, Y. S., Yu, H. K., Lee, B. Z., \& Hong, K. W. (2018). Effect of DNA extraction methods on the detection of porcine ingredients in halal cosmetics using real-time PCR. Applied Biological Chemistry, 61(5), 549-555.

Mohamad, N. A., Mustafa, S., Khairil Mokhtar, N. F., \& El Sheikha, A. F. (2018). Molecular beaconbased real-time PCR method for detection of porcine DNA in gelatin and gelatin capsules. Journal of the Science of Food and Agriculture, 98(12), 4570-4577.

Mustaqimah, D. N., Septiani, T., \& Roswiem, A. P. (2021). Deteksi Dna Babi Pada Produk Sosis Menggunakan Real Time-Polymerase Chain Reaction (Rt-Pcr). Indonesia Journal of Halal, 3(2), 106-111.

Panina, Y., Germond, A., Masui, S., \& Watanabe, T. M. (2018). Validation of Common Housekeeping Genes as Reference for qPCR Gene Expression Analysis During iPS Reprogramming Process. Scientific Reports, 8(1), 1-8.

Rachmawati, Y., Rokhim, S., Munir, M., \& Agustina, E. (2018). Deteksi Kontaminan Fragmen Dna Pengkode Cyt B Babi Pada Sampel Softgell Candy Tak Berlabel Halal. Indonesia Journal of Halal, $1(1), 25-30$.

Raharjo, T. J., Chudori, Y. N. C., \& Agustina, F. W. (2019). TaqMan Probe Real-Time Polymerase Chain Reaction Targeting the ATPase 6 Gene for the Detection of Pork Adulteration in Meat and Meatballs. Journal of Food Safety, 39(6), 1-6.

Rebouças, E. de L., Costa, J. J. do N., Passos, M. J., Passos, J. R. de S., Hurk, R. van den, \& Silva, J. R. V. (2013). Real Time PCR and Importance of Housekeepings Genes for Normalization and Quantification of mRNA Expression in Different Tissues. Brazilian Archives of Biology and Technology, 56(1), 143-154.

Septiani, T. (2021). Identification of Rat Meatballs in Traditional Market in Area of Jakarta Using Real Time - Pcr. Indonesia Journal of Halal, 3(1), 94-99.

Sudjadi, Wardani, H. S., Sepminarti, T., \& Rohman, A. (2016). Analysis of Porcine Gelatin DNA in a Commercial Capsule Shell Using Real-Time Polymerase Chain Reaction for Halal Authentication. International Journal of Food Properties, 19(9), 2127-2134.

Tan, L. L., Ahmed, S. A., Ng, S. K., Citartan, M., Raabe, C. A., Rozhdestvensky, T. S., \& Tang, T. H. (2020). Rapid Detection of Porcine DNA in Processed Food Samples Using a Streamlined DNA Extraction Method Combined With the SYBR Green Real-Time PCR assay. Food Chemistry, 309, $1-27$.

Tanabe, S., Hase, M., Yano, T., Sato, M., Fujimura, T., \& Akiyama, H. (2007). A real-time quantitative PCR detection method for pork, chicken, beef, mutton, and horseflesh in foods. Bioscience, Biotechnology and Biochemistry, 71(12), 3131-3135.

Taylor, S., Wakem, M., Dijkman, G., Alsarraj, M., \& Nguyen, M. (2010). A Practical Approach to RTqPCR-Publishing Data that conform to the MIQE guidelines. In Methods 50(4),

Waluyo, S., Sustiprijatno, S., \& Suharsono, S. (2016). Transformasi Genetik Tembakau Dengan Gen Cold Shock Protein Melalui Perantara Agrobacterium tumefaciens. Jurnal AgroBiogen, 9(2), 5865.

Widayat, W., Winarni Agustini, T., Suzery, M., Ni'matullah Al-Baarri, A., \& Rahmi Putri, S. (2019). Real Time-Polymerase Chain Reaction (RT-PCR) sebagai Alat Deteksi DNA Babi dalam Beberapa Produk Non-Pangan. Indonesia Journal of Halal, 2(1), 26-33.

Zhu, L., Zhang, Y., Hu, Y., Wen, T., \& Wang, Q. (2013). Dynamic actin gene family evolution in primates. BioMed Research International, 2013, 1-11. 